\title{
Documentation of Folkloric Knowledge on Medicinal Plants Used in the Treatment of Mouth Ulcers in Kodangal Mandal, Mahabubnagar District, Telangana, India
}

\section{Shivakumar Singh $\mathbf{P}^{1}$, Vidyasagar GM ${ }^{2 *}$, Rajendar Singh DSR ${ }^{3}$ and Bhagyanarayana $\mathbf{G}^{4}$}

${ }^{1}$ Department of PG Studies and Research in Botany, MVS Govt. Degree and PG College, Mahabub Nagar, Telangana, India

${ }^{2}$ Medicinal Plants and Microbiology Research Laboratory, Department of Post Graduate Studies and Research in Botany, Gulbarga University, Gulbarga, Karnataka, India ${ }^{3}$ SV Arts and Science, Degree and PG College, Palem, Telangana, India

${ }^{4}$ Palamuru University, Mahabubnagar, Telangana, India

\begin{abstract}
A total of 32 folkloric medicinal plants used in the treatment of mouth ulcers in Kodangal mandal, Mahabubnagar district, Telangana state have been documented using standard questioner. Of 32 plants species belonging to 31 genera and 22 families were found useful. The largest family Fabaceae was represented 04 species followed by Euphorbiaceae 03 species, whereas the five families, i.e., Apiaceae, Lythraceae, Lamiaceae, Myrtaceae and Verbenaceae represented by 2 of each species. While the 15 families represented single species each. Among parts used 20 plants species were used without ingredients, while 12 used with ingredients. The present report described them in detailed along with the method of drug preparation, mode of administration, probable dosage and duration of treatment. Maximum new findings on the ethnic practices were documented.
\end{abstract}

Keywords: Folkloric medicinal plants; Mouth ulcers

\section{Introduction}

The modus operandi of ethnic treatment has very deep root in Indian culture, the uses of the folkloric plants not only for curing diseases but also during various ceremonies. Right from beginning to man history, people have relied on ethno medicine and folkloric plants in particular to promote and maintain good health. This dependency of man on plant made him to acquire the knowledge on medicinal and economic properties of plants by trial and error methods. The occupy of traditional medicines and medicinal plants in most developing countries as curative agents for the continuation of good health has been extensively observed [1]. In India $65 \%$ of the residents depends on folkloric medicine, which is the only resource of their crucial health heed needs [2]. India is one of the twelve mega-biodiversity countries of the world having rich foliage with a spacious variety of plants with medicinal value. In excess of 550 tribal communities are roofed under 227 ethnic groups residing in about 5000 villages of India in different forests and vegetation types [3]. As a result, he gained both useful and detrimental information, accumulated, enriched through generations and passed on from generation to another without any written document. As it was a part of their culture, no written document of this skill and knowledge was required.

Documentation of folkloric knowledge on the uses of medicinal plants has provided many important drugs preparation, mode of action secrets from our fore fathers. Even today this area holds much more hidden treasure as almost $80 \%$ of the human population in developing countries is dependent on plant resources for healthcare. Though, the past 200 years have witnessed not only an acceleration in the rate of extinction of plant and animal species, but also the erosion of folkloric knowledge related to medicinal properties. May be, it is due to the advances in science, like molecules from plant in pure form and formulated the synthetic compounds for the treatment of various diseases. The ever-rising cost of the synthetic drug, its incompetence in several cases and its involvement with harmful side effects are some of the demerits leading man to re-think over the use of synthetic drugs for a longer period.

Consequently, since previous twenty five years, again the folkloric medicine is gaining importance all over the world. People realized the significance of documentation of folkloric knowledge on medicinal plants. Mouth ulcers are a common condition that affects the general population at one time or another. The majority of medication that has been used so far i.e. mouth washes and gels have the disadvantage of reduced contact time with the affected area. Oral hygiene is an integral part of health of a person. Oral health when neglected, results in different types of oral ailments like mouth ulcers, dental caries and periodontal diseases. Oral disorders can significantly affect the general well-being of a person by causing considerable pain and discomfort, thus affecting their quality of life [4]. The study area located at rural background of Telangana, where the people were not concentrating on their health and hygienic. There were no previous reports from the Telangana State on the folkloric medicinal plants against mouth ulcers, so the present report becomes a first and novel report.

\section{Materials and Method}

Regular field trips were undertaken to different localities of the study area during the period from May 2013 to Nov 2014. Localities were selected in such a way that they should represent the entire mandal including rural areas and tribal pockets. A list of folkloric practitioners belonging to different areas was prepared. Each locality was visited during different seasons and collected the information about the seasonal medicinal plants. During the fieldwork, frequent visits were made to the herbal practitioners and efforts were made to convince them to disclose their folkloric knowledge about the healing plants.

*Corresponding author: Vidyasagar GM, Medicinal Plants and Microbiology Research Laboratory, Department of Post Graduate Studies and Research in Botany, Gulbarga University, Gulbarga-585 106, Karnataka, India, Tel: +91 8472 269650; E-mail: gmvidyasagar@rediffmail.com

Received December 23, 2014; Accepted September 28, 2015; Published October 01, 2015

Citation: Shivakumar Singh P, Vidyasagar GM, Rajendar Singh DSR, Bhagyanarayana G (2015) Documentation of Folkloric Knowledge on Medicinal Plants Used in the Treatment of Mouth Ulcers in Kodangal Mandal, Mahabubnagar District, Telangana, India. J Bioanal Biomed 7: 174-179. doi:10.4172/1948593X.1000140

Copyright: $\odot 2015$ Shivakumar Singh P, et al. This is an open-access article distributed under the terms of the Creative Commons Attribution License, which permits unrestricted use, distribution, and reproduction in any medium, provided the original author and source are credited. 
Citation: Shivakumar Singh P, Vidyasagar GM, Rajendar Singh DSR, Bhagyanarayana G (2015) Documentation of Folkloric Knowledge on Medicinal Plants Used in the Treatment of Mouth Ulcers in Kodangal Mandal, Mahabubnagar District, Telangana, India. J Bioanal Biomed 7: 174-179. doi:10.4172/1948-593X.1000140

The information about the plants was recorded by means of discussions and interviews using standard questionnaire [5] with the informers along with the field visits during the collection hours. The information was gathered like local name(s) of the plant, parts used methods of preparation. The information about the ingredients added, methods of administration or application, dose and duration of medication and associated medicated food was also recorded in few cases.

The collected plant specimens were authentically identified with the help of floras such as, Flora of Andhra Pradesh [6], Flora of British India [7], and Flora of Gulbarga District [8] and the voucher numbers were given and herbarium specimens were prepared. Telangana is a $29^{\text {th }}$ state of India. It comprises 10 districts. Mahabubnagar district is one of the biggest districts of Telangana state, it is located south west region of Telangana, latitude between $15^{\circ} 55^{\prime}$ and $17^{\circ} 29^{\prime} \mathrm{N}$, longitude between $77^{\circ} 15^{\prime}$ and $79^{\circ} 15^{\prime} \mathrm{E}$, area 18,432 sq. $\mathrm{km}$, the present study area Kodangal mandal is also one of the 64 mandals. This mandal area in 242.0 sq. Km, population in persons 48, 299 and density 200 (per sq. $\mathrm{km}$ ). The people of this mandal were economically little backward. They can speak four languages, knowledge flows from one culture to other. The plant diversity is very rich and a good number of medicinal plants are used in the treatment of various diseases including mouth ulcers. Therefore, the present study focused on the documentation of folkloric knowledge on medicinal plants used in the treatment of mouth ulcers (Figure 1).

\section{Results}

In the present folkloric botanical report, a total of 32 folkloric medicinal plants used in the treatment of mouth ulcers in Kodangal mandal, Mahabub nagar district, Telangana state have been documented using standard questioner. Of 32 plants species belonging to 31 genera and 22 families were found useful. The largest family
Fabaceae was represented 04 species followed by Euphorbiaceae 03 species, whereas the five families i.e., Apiaceae, Lythraceae, Lamiaceae, Myrtaceae and Verbenaceae represented by 2 of each species. While the 15 families represented single species each. Among parts used 20 plants species were used without ingredients, while 12 used with ingredients. The present report described them in detailed along with the method of drug preparation, mode of administration, probable dosage and duration of treatment. Maximum new findings on the ethnic practices were documented.

\section{Discussion}

Data was compared with the available previous literature and found that many of the usages listed are not recorded earlier [9]. Earlier there were no reports on mouth ulcers from the present study area. This is first and unique report. Frequency in distribution sources, Percentage in distribution of growth forms, Distribution of medicinal plants into taxonomic groups, Frequency in distribution of plant parts of medicinal plants against mouth ulcers was analyzed. Frequency distribution sources of medicinal plants in the study area against mouth ulcers shown in Figure 2. Of 32 plants species documented, shows that both the (Cultivated and Wild) share the largest proportion with 15 species $(46.87 \%)$ followed by Wild (In-situ) with 09 species $(28.12 \%)$ and Cultivated (Ex-situ) with 08 species (25\%).

The analysis of habits (Figure 2) of plants documented, shows that trees share the largest proportion with 13 species (40.62\%) followed by shrubs with 10 species $(31.25 \%)$, herbs with 08 species $(25.00 \%)$ and climbers with 1 species (03.12\%) (Figure 3).

\section{Distribution of medicinal plants into taxonomic groups}

The genus Phyllanthus has 2 species each. The remaining genera

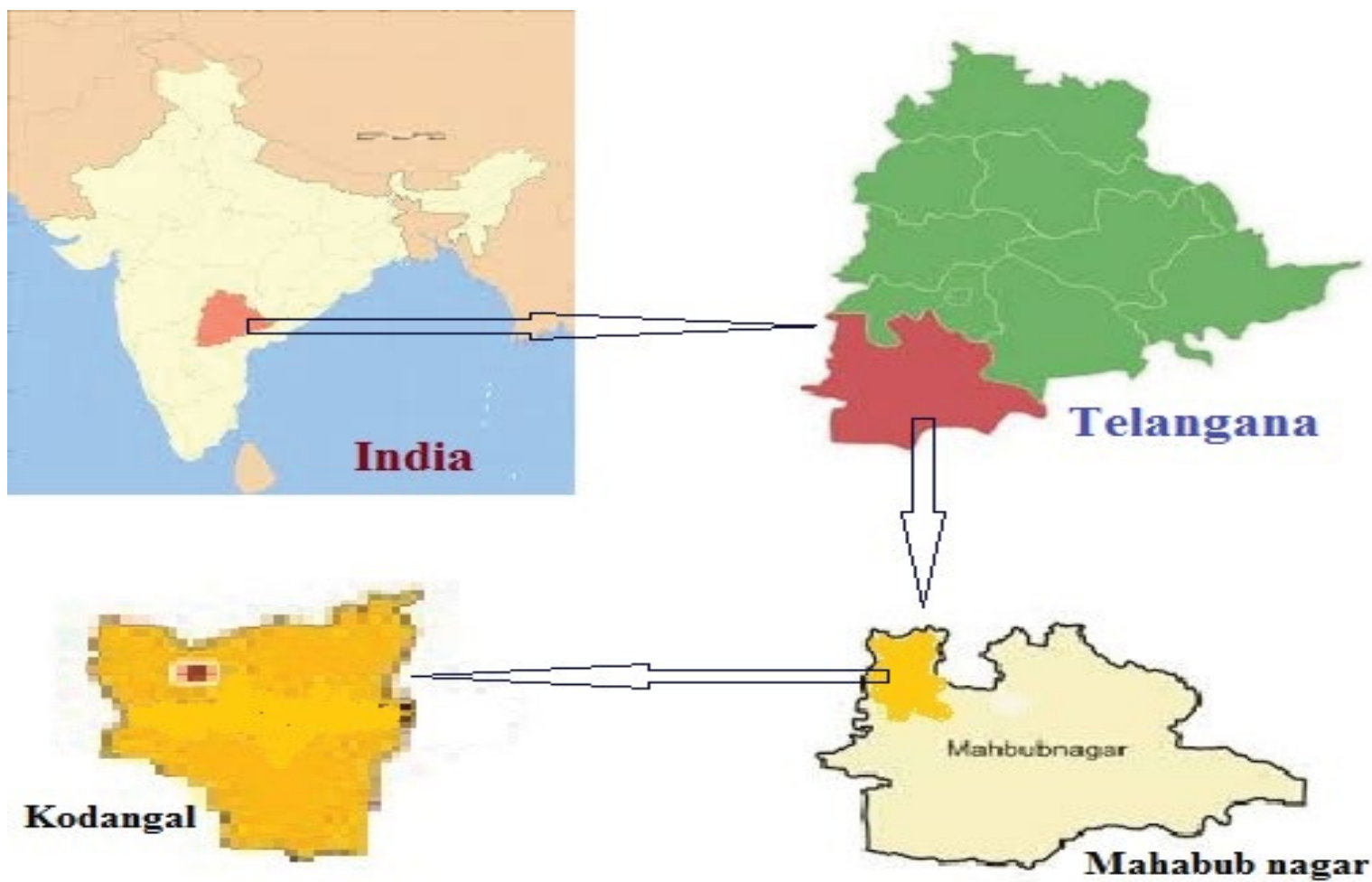

Figure 1: Study area Kodangal Mandal, Mahabub nagar district, Telangana, India. 
Citation: Shivakumar Singh P, Vidyasagar GM, Rajendar Singh DSR, Bhagyanarayana G (2015) Documentation of Folkloric Knowledge on Medicinal Plants Used in the Treatment of Mouth Ulcers in Kodangal Mandal, Mahabubnagar District, Telangana, India. J Bioanal Biomed 7: 174-179. doi:10.4172/1948-593X.1000140

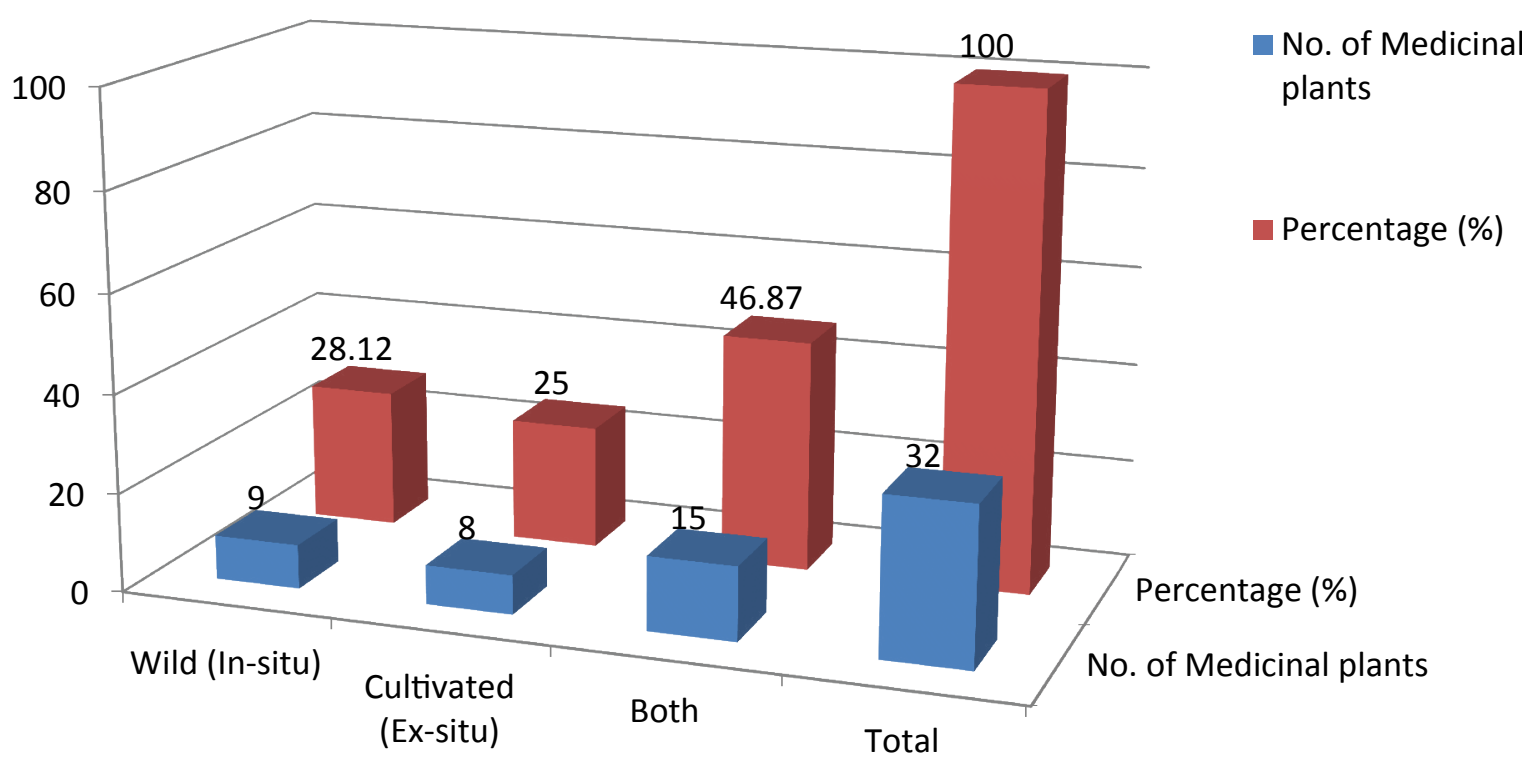

Figure 2: Frequency distribution of sources of medicinal plants in the study area against mouth ulcers.

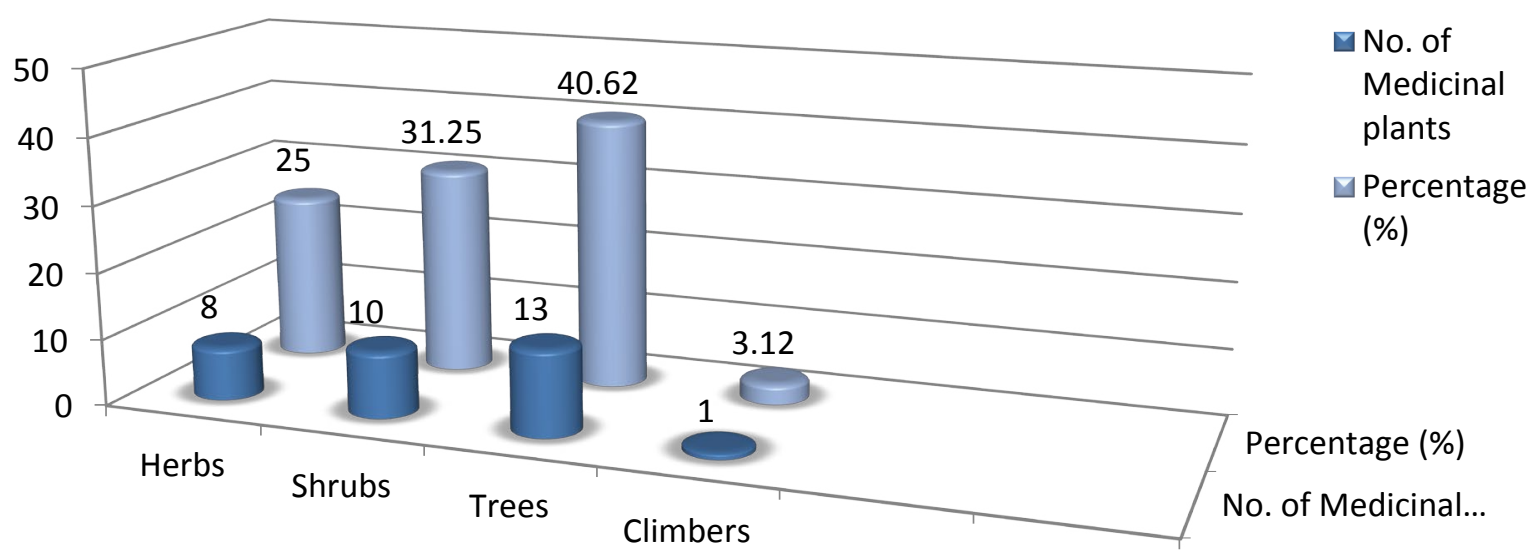

Figure 3: Percentage distribution of growth forms of medicinal plants recorded against mouth ulcers.

with one species each with respect to families, Fabaceae was shared the largest proportion, i.e., consisted of 4 species each, followed by Euphorbiaceae 3 species, Apiaceae, Lythraceae, Lamiaceae, Myrtaceae and Verbenaceae 2 species each and the remaining 15 families with 1 species each. The analysis of method of preparation indicated that plant parts are often rendered into different forms of remedies in accordance with the type of ailment to be treated and the medical history of the subject patient. In this regard, from a total of 32 preparations (Table 1), oral mixture takes the highest share which account for about $56.4 \%$, followed by topical having a share of $40.2 \%$. Despite the existence of variations of knowledge on preparation of remedies amongst different cultures, local people often tend to make remedies that look alike some extent. This is due to the fact that indigenous knowledge (IK) related to use of plant for healthcare maintenance is the reflection of the types and density of flora and fauna found in a given locality and the cultural background of the society in that area (Figures 4 and 5).
In the present report Lawsonia inermis L. shade dried leaves is used with other ingredients in the preparation of mouth ulcers treating medicine but in previously Maji Jose et al., used only fresh leaves. Whereas Jatropha curcas L. latex used in this report while in previously the stem and decoction of leaves used in the treatment of mouth ulcers [10]. The Rajasthanees using Jatropha species in treating routine oral hygiene [11]. Hebber et al., [12] reported 35 plants belonging to 26 families used to treat different oral ailments from Western Ghat region of Dharwad district of Karnataka. Chopra RN et al., [13] reported traditional medicinal plants curing dental caries. Cinnamon plant parts have been reported and authentically inhibit the growth of oral microbes [14]. Sonowal Kachari [15] reported two medicinal plants for mouth washing from tribe of Dibrugarh district in Assam. The present report maximum is not being correlated with the previous review data of Pradeep Kumar R [16], where 120 species of plants from 46 families recorded. So that it would be the considered a novel publication. 
Citation: Shivakumar Singh P, Vidyasagar GM, Rajendar Singh DSR, Bhagyanarayana G (2015) Documentation of Folkloric Knowledge on Medicinal Plants Used in the Treatment of Mouth Ulcers in Kodangal Mandal, Mahabubnagar District, Telangana, India. J Bioanal Biomed 7: 174-179. doi:10.4172/1948-593X.1000140

\begin{tabular}{|c|c|c|c|c|}
\hline Plant name & Family & Parts used & Local name & Mode of use and Suggested medical practitioner reference number \\
\hline $\begin{array}{l}\text { Annona squamosa L. } \\
\text { HMVS-19 }\end{array}$ & Annonaceae & Flower & $\begin{array}{l}\text { Seetha phala } \\
\text { chettu }\end{array}$ & 1-2 Flower buds chew early morning for $4-5$ days. \\
\hline $\begin{array}{l}\text { Argemone mexicana L. } \\
\text { HMVS-61 }\end{array}$ & Papaveraceae & Latex & Jeripothu alamu & Yellow fresh latex is applied on ulcer point. \\
\hline $\begin{array}{l}\text { Azadirachta indica } \\
\text { HMVS-14 }\end{array}$ & Miliaceae & $\begin{array}{l}\text { Young stem } \\
\text { bark }\end{array}$ & Vepa chettu & Fresh bark peel juice is applying on mouth ulcers thrice a day till it cures. \\
\hline $\begin{array}{l}\text { Bergera koenigii L. } \\
\text { HMVS-51 }\end{array}$ & Rutaceae & Leaf & Kalepaku chettu & $\begin{array}{l}5-6 \text { spoons of fresh leaves juice with } 1 \text { spoons of honey is taken twice a day for } \\
4-5 \text { days. }\end{array}$ \\
\hline $\begin{array}{l}\text { Butea monosperma (Lam.) Taub. } \\
\text { HMVS-50 }\end{array}$ & Fabaceae & Leaf & Muduga & Daily twice mouth pulling with petiole decoction is cures mouth ulcer. \\
\hline $\begin{array}{l}\text { Cajanus cajan (L.)Mill. } \\
\text { HMVS- } 515\end{array}$ & Fabaceae & Leaf & Kandi & Chewing 4-6 leaves twice a day for a week. \\
\hline $\begin{array}{l}\text { Cassia alata L. } \\
\text { HMVS-33 }\end{array}$ & Ceasalpiniaceae & $\begin{array}{l}\text { Leaves \& } \\
\text { flowers }\end{array}$ & Avichi chettu & Decoction of leaves and flowers is used mouth pulling for a month. \\
\hline $\begin{array}{l}\text { Coccus nucifera L. } \\
\text { HMVS-12 }\end{array}$ & Arecaceae & Fruit & Kebbera & Dried coconut chewing twice a day relief from ulcers pain. \\
\hline $\begin{array}{l}\text { Coriandrum sativum L. } \\
\text { L. HMVS-22 }\end{array}$ & Apiaceae & Ariel & Kothimir & Chewing ariel parts with leaves twice a day till it cures. \\
\hline Cuminum cyminum L. HMVS-74 & Apiaceae & Seed & Jeera & $\begin{array}{l}\text { 2-3 spoons of jeera soaked in } 50 \mathrm{ml} \text { of water with (Navothu/ misri) type of sugar } \\
\text { over night and take with empty stomach for a week. }\end{array}$ \\
\hline $\begin{array}{l}\text { Ficus bengalensis L. } \\
\text { HMVS- } 80\end{array}$ & Moraceae & $\begin{array}{l}\text { Terminal } \\
\text { buds }\end{array}$ & Marri chettu & Terminal buds chewing gives relief from mouth ulcers. \\
\hline $\begin{array}{l}\text { Gymnosporia montana (Roth) } \\
\text { Benth HMVS-34 }\end{array}$ & Celastraceae & Leaf & Dante & 2-4 leaves chewing twice a day till it cures. \\
\hline $\begin{array}{l}\text { Jatropha curcas L. } \\
\text { HMVS- } 27\end{array}$ & Euphorbiaceae & Latex & Napalamun & Milky latex applied on mouth ulcers. \\
\hline $\begin{array}{l}\text { Launaea procumbens (Roxb). } \\
\text { HMVS-48 }\end{array}$ & Asteraceae & Leaf & Adavi gobi & The decoction of 5-6 leaves is taken with empty stomach for a week. \\
\hline $\begin{array}{l}\text { Lawsonia inermis L. } \\
\text { HMVS-94 }\end{array}$ & Lythraceae & $\begin{array}{l}\text { Terminal } \\
\text { buds }\end{array}$ & Midaku & $\begin{array}{l}\text { Terminal buds of Lawsonia and equal amount of jeera were made into smooth } \\
\text { paste add two tea spoons of mishre mix well, made small tablets then take daily } \\
\text { twice morning with empty stomach and night before going to bed. }\end{array}$ \\
\hline $\begin{array}{l}\text { Mangifera indica L. } \\
\text { HMVS-52 }\end{array}$ & Anacardiaceae & Seed & Mamidi & Unripe fruit seed paste is applied on mouth ulcers daily thrice till it cures. \\
\hline $\begin{array}{l}\text { Mentha viridis L. } \\
\text { HMVS-10 }\end{array}$ & Lamiaceae & Leaf & Podina & $\begin{array}{l}\text { 2-3 spoons of dried leaves powder with warm water are taken empty stomach for } \\
\text { a week. }\end{array}$ \\
\hline $\begin{array}{l}\text { Momordica charantia L. HMVS- } \\
84\end{array}$ & Cucurbitaceae & $\begin{array}{l}\text { Dried fruit } \\
\text { pulp }\end{array}$ & Kakar kaya & $\begin{array}{l}\text { 1-2 spoons of dried fruit pulp with } 2-3 \text { spoons of lemon juice mixed in approximately } \\
\text { about } 100 \mathrm{ml} \text { of water is taken twice a day for a week. }\end{array}$ \\
\hline $\begin{array}{l}\text { Ocimum sanctum L. } \\
\text { HMVS-532 }\end{array}$ & Lamiaceae & Leaf & Tulasi & $\begin{array}{l}\text { Leaves, fresh curcuma take equal amount and made smooth paste add one } \\
\text { teaspoon of fresh honey }\end{array}$ \\
\hline Phyllanthus emblica L. HMVS-92 & Euphorbiaceae & $\begin{array}{l}\text { Dried fruit } \\
\text { powder }\end{array}$ & Nela usiri & $\begin{array}{l}2-3 \text { spoons of dried fruit powder and } 1 \text { spoon of honey with } 50 \mathrm{ml} \text { of water for twice } \\
\text { a day taken } 4-5 \text { days. }\end{array}$ \\
\hline $\begin{array}{l}\text { Phyllanthus reticulates Poir. } \\
\text { HMVS--34 }\end{array}$ & Euphorbiaceae & $\begin{array}{l}\text { Young stem } \\
\text { bark }\end{array}$ & Pulichara chettu & Young stem bark chewing cures the mouth ulcers. \\
\hline $\begin{array}{l}\text { Pithacalobium dalsi L. } \\
\text { HMVS-77 }\end{array}$ & Fabaceae & Fresh fruit & Seema chintha & Eat 2-4 immature fruits thrice a day, it cures mouth ulcers immediately. \\
\hline $\begin{array}{l}\text { Psidium guajava L. } \\
\text { HMVS-78 }\end{array}$ & Myrtaceae & Leaves & Jama & Decoction of leaves is swishing every morning for a month. \\
\hline $\begin{array}{l}\text { Punica granatum L. } \\
\text { HMVS-79 }\end{array}$ & Lythraceae & Seed & $\begin{array}{l}\text { Daanimma } \\
\text { chettu }\end{array}$ & $\begin{array}{l}\text { 2-3 tea spoon of dried seed powder, pinch of curcuma powder add to glass of cow } \\
\text { milk and taken before going to bed, for a week. }\end{array}$ \\
\hline $\begin{array}{l}\text { Solanum nigrum L. } \\
\text { HMVS-83 }\end{array}$ & Solanaceae & Leaf & $\begin{array}{l}\text { Kashabusha } \\
\text { chettu }\end{array}$ & Applying of fresh leaves juice on mouth ulcers twice a day for $5-6$ days. \\
\hline $\begin{array}{l}\text { Syzygium aromaticum (L.) } \\
\text { Merr. \& Perry } \\
\text { HMVS-88 }\end{array}$ & Myrtaceae & Flower buds & Lavanga & Juice of flower bud with honey is applying on ulcer, twice a day for 5-6 cures. \\
\hline $\begin{array}{l}\text { Tectona grandis L. f. } \\
\text { HMVS-84 }\end{array}$ & Verbenaceae & Leaf base & Teku & Leaf base juice is applying on ulcer thrice day, till it cures. \\
\hline $\begin{array}{l}\text { Terminalia chebula L. } \\
\text { HMVS- } 86\end{array}$ & Combretaceae & Fruits & karaka & Fruit paste is mixed with honey and applied on ulcers, it cures within 3-4 days \\
\hline $\begin{array}{l}\text { Vachellia nilotica (L.) P.J.H.Hurter } \\
\text { \& Mabb. HMVS-89 }\end{array}$ & Fabaceae & Leaves & Nalla thumma & $\begin{array}{l}\text { Decoction of young leaves is used for mouth pulling in the early morning for a } \\
\text { month. Chewing gum of this plant is cures mouth ulcers. }\end{array}$ \\
\hline $\begin{array}{l}\text { Vitex negundo L. } \\
\text { HMVS-101 }\end{array}$ & Verbenaceae & $\begin{array}{l}\text { Terminal } \\
\text { buds }\end{array}$ & Vailu chettu & Chewing 2-3 young leaves daily once till it cures. \\
\hline $\begin{array}{l}\text { Zingiber officinale Rosce. HMVS- } \\
100\end{array}$ & Zingiberaceae & Rhizome & Allam & 2 tea spoon of fresh rhizome juice with 1 tea spoon of honey takes twice a day. \\
\hline $\begin{array}{l}\text { Zizyphus jujuba Lam. } \\
\text { HMVS- } 60\end{array}$ & Rhamnaceae & Leaves & Neredu & Pulling of olden leaves decoction for a week is cures mouth ulcers. \\
\hline
\end{tabular}

Table 1: Medicinal plant used against mouth ulcer by rural people of Kodangal mandal, Mahabub nagar district, Telangana, India. 
Citation: Shivakumar Singh P, Vidyasagar GM, Rajendar Singh DSR, Bhagyanarayana G (2015) Documentation of Folkloric Knowledge on Medicinal Plants Used in the Treatment of Mouth Ulcers in Kodangal Mandal, Mahabubnagar District, Telangana, India. J Bioanal Biomed 7: 174-179. doi:10.4172/1948-593X.1000140

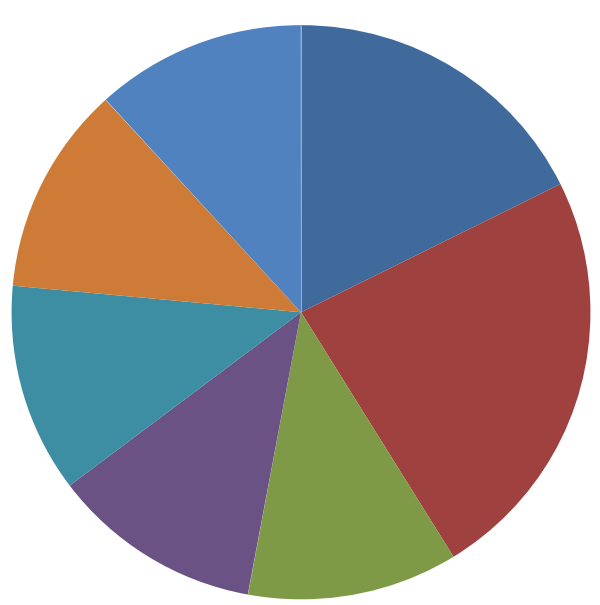

Euphorbiaceae
Fabaceae
Lamiaceae
Verbenaceae

Figure 4: 32 medicinal plants distribution family wise against mouth ulcers.

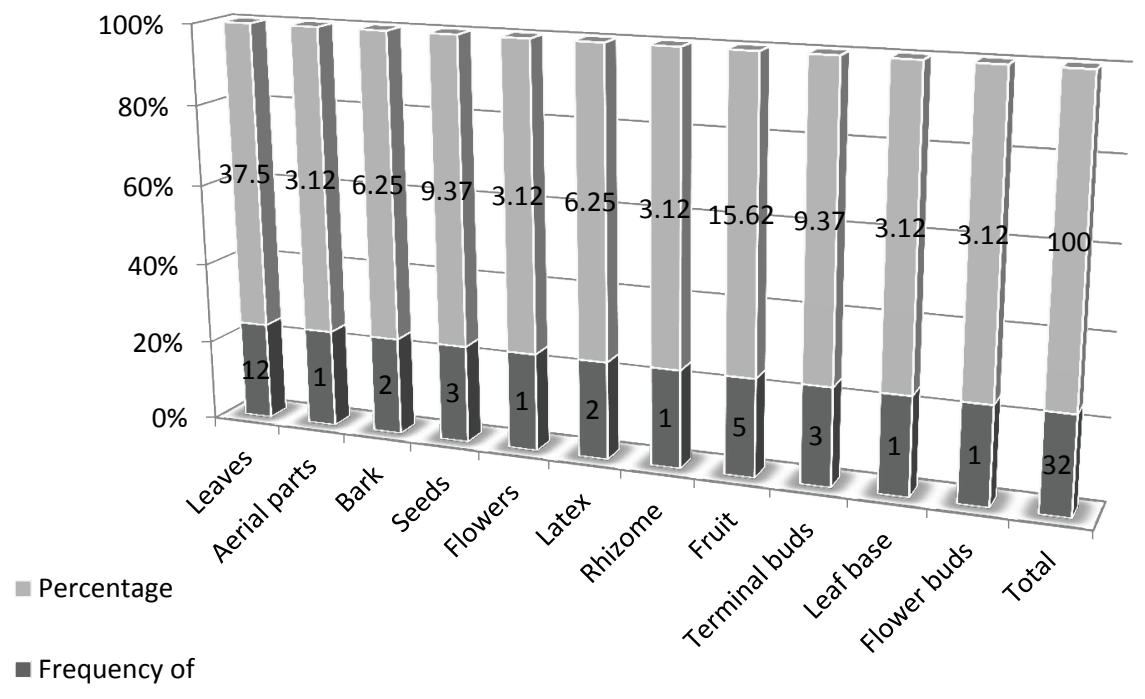

occurrence

Figure 5: Frequency distribution of plant parts used against mouth ulcers.

\section{Conclusion}

The conservation of folkloric medicinal plants not only protects the tribal lives, but also improves the socio economic situation of the people. The results of the present report have been given detailed data on the folkloric medicinal plants used in the treatment of mouth ulcers in Kodangal mandal, Mahabub nagar District, Telangana, India. This study gives foundation for further phytochemical and pharmacological studies.

\section{Acknowledgement}

Authors are grateful to the folkloric practitioners and rural people of Kodangal mandal, Mahabubnagar distt. Telangana state for sharing their wisdom on medicinal plants.

\section{References}

1. UNESCO (1996) Culture and Health, Orientation texts- World Decade for Cultural Development Documents CLT/DEC.

2. Rajasekharan S, Pushpangadan P, Biju SD (1996) Folk Medicines of Kerala A Study on Native Traditional Folk Healing Art and its Practitioners. Deep Publications, New Delhi.
3. Sikarwar RLS (2002) Ethnogynaecological uses of plants new to India. Ethno botany 14: 112-115.

4. Sheiham A (2005) Oral health, general health and quality of life. Bull World Health Organ 83: 644.

5. Ethnoveterinary Studies in Uttar Pradesh.

6. Pullaiah (2010) Flora of Andhra Pradesh.

7. Hooker JD (1978) Flora of British India Vol. 1-7.

8. Seetharam YN, Kotresh K, Uplaonkar SB (2000) Flora of Gulbarga district (Gulbarga University, Gulbarga).

9. Rout SD, Panda, Mishra N (2009) Ethno-medicinal Plants Used to Cure Different Diseases by Tribals of Mayurbhanj District of North Orissa. EthnoMed 3: 27-32.

10. Maji Jose, Bhagya B, Shantaram M (2011) Ethnomedicinal Herbs Used in Ora Health and Hygiene in Coastal Dakshina Kannada. J Oral Health Comm Dent 5: 119-123.

11. Bhasin V (2004) Oral Health Behaviour among Bhils of Rajasthan. Journal of Social Science 8: 1-5.

12. Hebbar SS, Harsha VH, Shripathi V, Hegde GR (2004) Ethnomedicine of Dharwad district in Karnataka, India--plants used in oral health care. J Ethnopharmacol 94: 261-266. 
Citation: Shivakumar Singh P, Vidyasagar GM, Rajendar Singh DSR, Bhagyanarayana G (2015) Documentation of Folkloric Knowledge on Medicinal Plants Used in the Treatment of Mouth Ulcers in Kodangal Mandal, Mahabubnagar District, Telangana, India. J Bioanal Biomed 7: 174-179. doi:10.4172/1948-593X.1000140

13. Chopra RN, Chopra IC, Handa KL (1958) Chopra's indigenous drugs of India. $\left(2^{\text {nd }}\right.$ edition) Calcutta: UN Dhur and Sons.

14. Saeki Y, Ito Y, Shibata M, Sato Y, Okuda K, et al. (1989) Antimicrobial action of natural substances on oral bacteria. Bull Tokyo Dent Coll 30: 129-135.
15. Ripunjoy S (2013) Indigenous Knowledge on the Utilization of Medicinal Plants by the Sonowal Kachari Tribe of Dibrugarh District in Assam, North-East India. Int Res J Biological Sci 2: 44-50.

16. Pradeep Kumar R (2014) Ethno medicinal plants used for oral health care in India. International Journal of Herbal Medicine 2: 81-87. 